\title{
Output-Classes for Faculty-Based Design-Oriented Research on Digital Learning Resources in Higher Education
}

\author{
Rob J. M. Hartog \\ Wageningen MultiMedia Research Centre, \\ Huub Scholten and Adrie J. M. Beulens \\ Information Technology Group \\ Wageningen University, Wageningen, The Netherlands
}

\section{rob.hartog@wur.nl; huub.scholten@wur.nl; adrie.beulens@wur.nl}

\begin{abstract}
Digital learning resources are essentially knowledge-intensive information systems. In higher education, advance of interactive digital learning resources will primarily require design-oriented efforts by faculty. Growth of knowledge on digital learning resources and learning objects in higher education implies design, realization, use, implementation and evaluation of digital learning resources as well as sharing knowledge in scientific publications. Over the last fifteen years a range of projects involving such design-oriented activities in natural, engineering, management, decision and information sciences has been carried out. There is a growing body of literature on various design-related research approaches in educational research and in information systems research. However, for faculty-based design-oriented research the question what knowledge should be shared in scientific publications is not yet clearly answered. This article relates this question to the transdisciplinary nature of faculty-based design-oriented research. The article proposes an answer to this question in terms of a set of result types or output-classes. For each output-class it is explained why a contribution in that class can provide a valuable addition to the body of knowledge on digital learning resources in higher education.
\end{abstract}

Keywords: design-oriented research, digital learning materials, digital learning resources, faculty-based design, theory-relevance gap, scholarship of teaching and learning, higher education.

\section{Introduction}

In most universities, teaching responsibilities imply that faculty invests efforts in the design of learning scenarios and learning resources. Examples of learning scenarios are lecture-based scenarios, scenarios for laboratory classes and problem-based learning scenarios. Examples of traditional learning materials are slide presentations, textbooks and laboratory manuals. In the last

Material published as part of this publication, either on-line or in print, is copyrighted by the Informing Science Institute. Permission to make digital or paper copy of part or all of these works for personal or classroom use is granted without fee provided that the copies are not made or distributed for profit or commercial advantage AND that copies 1) bear this notice in full and 2) give the full citation on the first page. It is permissible to abstract these works so long as credit is given. To copy in all other cases or to republish or to post on a server or to redistribute to lists requires specific permission and payment of a fee. Contact Publisher@,InformingScience.org to request redistribution permission. decade, an increasing number of faculty members also invest efforts in the design, realization, implementation and use of digital learning resources in their courses.

In line with calls for faculty to invest effort in 'scholarship of teaching and learning' (Boyer, 1990; Laurillard, 2008; Shulman, 2001; Trigwell, Martin, Benjamin, \& Prosser, 2000) it makes sense 
to share knowledge resulting from such faculty-based efforts by means of publications in peerreviewed journals. Examples of publications on faculty-based design, realization, implementation, use and evaluation of innovative digital learning resources aimed at courses in domains such as molecular biology, food science, food chemistry, biotechnology, human nutrition and epidemiology are listed in (WMMRC, 2007). The research reported in these publications was carried out within chair groups at Wageningen University. In the remainder of this article these projects will be referred to as 'WU' projects. The WU projects were design-oriented in the sense that most of the efforts were aimed to arrive at a design of specific digital learning resources.

In faculty-based design-oriented research that aims at innovative digital learning resources one can distinguish various categories of stakeholders (Ritzhaupt, 2010). The primary stakeholders and problem owners in, what we call 'faculty-based' projects, are the chair holder and faculty members within a university department. Such a project will in general require thorough subject matter expertise, which is often also discipline-specific. In such a project, most of the actual design and realization of the digital learning resources will be carried out by researchers who have a position within this chair group. In many universities faculty can be supported by ICT departments and faculty development departments.

Apart from subject matter knowledge and pedagogical content knowledge (Abell, 2008; T. R. Anderson, 2007; Shulman, 1987), the design rationale in these projects will touch upon many knowledge domains that are not covered by the discipline of the chair group. Examples of these other domains are information and communication technology (ICT), learning technology, instructional design, pedagogy, assessment methodology, management of organizations, knowledge management, human computer interaction, design, and research methodology. For designoriented research on digital learning resources that takes into account these various knowledge domains it is not obvious what research output to publish in which journal.

\section{Problem, Objective and Method}

Until about fifteen years ago, journals in many disciplines, in particular in information systems research and educational research disciplines, have seldom published design-related research papers. Now, there is a growing body of literature on various design-related research approaches in educational research and in information systems research. However, for faculty-based designoriented research (FB DOR), the question what knowledge can be potentially valuable and valid output for publication is not yet clearly answered.

An extensive search for publications in the last decade that provide insight in output from facultybased design-oriented efforts on digital learning materials resulted in a rather short list (J. Anderson \& DiCarlo, 2000; Aziz, Esche, \& Chassapis, 2007; Barak \& Dori, 2005; Barak, Harward, Kocur, \& Lerman, 2007; Breakey, Levin, Miller, \& Hentges, 2008; Coffey \& Koonce, 2008; Costelloe, Sherry, \& Magee, 2009; Deek \& McHugh, 2003; Ebner \& Holzinger, 2007; Gerosa, Fuks, \& Lucena, 2003; Gütl \& Pivec, 2003; Holzinger, Emberger, Wassertheurer, \& Neal, 2008; Holzinger, Kickmeier-Rust, Wassertheurer, \& Hessinger, 2009; Jensen, 2009; Jeschke, Richter, Scheel, \& Thomsen, 2007; Krauss \& Ally, 2005; Limniou \& Whitehead, 2010; Miller \& Upton, 2008; Navarro \& Hoek, 2005; Ong \& Mannan, 2004; Reyes-Palomares, Sánchez-Jiménez, \& Medina, 2009; Rodríguez-Caso, Sánchez-Jiménez, \& Medina, 2002; Saade, Nebebe, \& Mak, 2011; Sandvoss et al., 2003; Shanklin et al., 2003; Shin, Yoon, Lee, \& Lee, 2002; Siddiqui, Khan, \& Akhtar, 2008; Stone, 2007; Toumoto, Horiguchi, Hirashima, \& Takeuchi, 2006; Yen \& Li, 2003; Yokaichiya, Galembeck, \& Torres, 2004; Zimmerer, Thiele, Salzer, Krauseneck, \& Körndle, 2003). Insofar these publications are based on a common paradigm that clarifies what knowledge resulting from FB DOR should be shared in scholarly publications, this paradigm is very implicit. We consider this to be a problem, in particular in design-oriented $\mathrm{PhD}$ projects. 
This article addresses the lack of a paradigm for faculty-based design-oriented research in higher education. The objective of this article is to contribute to the articulation and elaboration of such a paradigm by proposing a set of result types or output classes. As such, the article is presented as an academic essay that contributes to the evolution of a paradigm and methodology for FB DOR.

The description of the output-classes can be regarded as an articulation of design-oriented information systems research (Österle et al., 2011) for the specific context of FB DOR on digital learning resources. Each of the output-classes is well-known in some engineering discipline, systems analysis and development literature and instructional design literature.

Insofar instances of outputs in the proposed output-classes have been produced in WU projects, they are used as illustration of the description of such output-classes. The FB DOR framework is the result of literature research and reflection on the publications from WU projects, rather than input of these WU projects. Like any such framework, the FB DOR framework makes visible where individual instances are 'incomplete'.

\section{Roadmap}

The next section provides a short review of various design-related research approaches, in particular in the fields of educational research and information systems research. Unfortunately, much of the literature on design-related research approaches is rather implicit with respect to the meaning of the term 'design'. Moreover, various disciplines attach different meanings to the term 'design'. Therefore, the following section shortly describes a model of design that focusses on constraints as unifying and basic concept in design literature.

In the next five sections each output-class is described, discussed and illustrated with examples or references to examples. The final section presents our concluding remarks.

Note that this article focusses on the output-classes and not on the process of arriving at instances of outputs in these classes. Nevertheless, a simplified Gantt chart of an abstract FB DOR project may help to keep track of the structure of the article. Therefore, figure 1 shows for each outputclass the corresponding task of producing output in that class. The area associated to each task in Figure 1 provides a suggestion of the time and capacity needed to produce output in that class. 


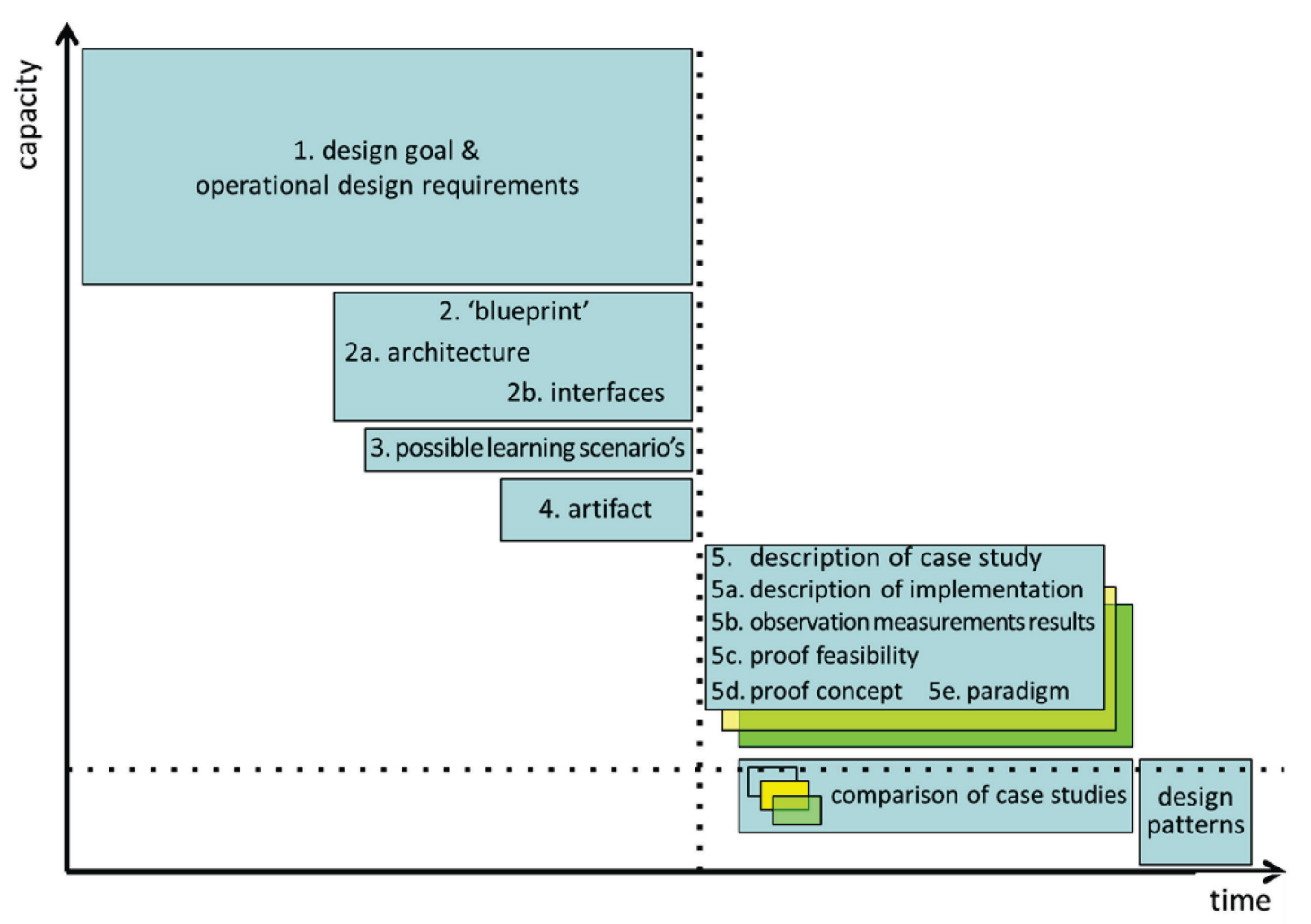

Figure 1: A qualitative extended Gantt Chart for DOR aiming at digital learning resource The rectangles denote tasks. The labels in the tasks are the output-classes, not the tasks. Each label should be read as 'Produce an instance of < output-class in label $>$. The numbers correspond with the numbering of the output-classes in the body of the manuscript. With one artifact several case studies can be carried out. The artifact and one learning scenario must be ready before the first case study (see vertical dashed line). In the figure, the blueprint is also ready before the first case study. However, the 'blueprint' can also be delivered much later, or not at all! Only one possible ordering of tasks in time is displayed. In the area below the horizontal dashed line there will be more activities that fall outside the scope of this article.

\section{Design-related Research Approaches}

There is a huge body of literature on design-related research approaches in a variety of disciplines (Barab, Thomas, Dodge, Carteaux, \& Tuzun, 2005; Bell, Hoadley, \& Linn, 2004; Burkhardt, 2006; Cobb, Confrey, diSessa, Lehrer, \& Schauble, 2003; Dede, 2004; Design-Based Research Collective, 2003; Eekels \& Roozenburg, 1991; Fallman, 2007; Gravemeijer \& Cobb, 2006; Hartog, Beulens, \& Tramper, 2010; Hevner, March, Park, \& Ram, 2004; Holmström, Ketokivi, \& Hameri, 2009; A. Kelly, 2004; A. E. Kelly, 2006; Kroes, 2002; Kuechler \& Vaishnavi, 2011; Laffey, Amelung, \& Goggins, 2009; Lijnse, 2003; March \& Smith, 1995; McKenney \& van den Akker, 2005; Moonen, 1999; Österle, et al., 2011; Peffers, Tuunanen, Rothenberger, \& Chatterjee, 2007; Richey \& Klein, 2007; Richey, Klein, \& Nelson, 2004; Sjostrom \& Agerfalk, 2009; van Aken, 2005; van den Akker, Gravemeijer, McKenney, \& Nieveen, 2006a, 2006b; VisscherVoerman, 1999a, 1999b). This literature reflects that many scholars in a range of disciplines strive for articulation of design-related research approaches. Many remarks can be found in the 
body of design-related research literature suggesting that design-related research approaches are still in a state of development in which terminology is not yet stable and ambitions fluctuate. Moreover, various disciplines often have different research paradigms and traditions (see for instance Mingers, 2001; Patton, 2002; Ziman, 2002) and, correspondingly, design-related research approaches in various disciplines tend to be different as well.

In particular, the following characteristics of purpose and context of faculty-based design, realization, implementation, use and evaluation of digital learning resources are difficult to match with assumptions in available literature on design-related research approaches.

Firstly, the practitioners who contribute most to the design of digital learning resources are university researchers. These researchers are likely to take into account the scientific norms and values of their own discipline. With some exceptions, the design-related research approaches that are described in existing literature, in particular in education, are mostly carried out by researchers of disciplines that are not the disciplines of the practitioners. These researchers publish in their own disciplinary journals, which do not aim at practitioners and in particular not at researchers in natural and engineering sciences.

Secondly, many publications on design-related research approaches in education assume contexts that are typical for primary or secondary education. These publications are often about 'interventions' that are 'enacted' by practitioners. However, in university education the following characteristics of context are important (Lundvall, Hargreaves, \& Saussois, 2000).

- Professors define, set and have to set their purposes and their own standards to a relatively large extent.

- There is constant pressure to change these purposes and standards.

- The range of tasks includes research, scholarship, teaching, consultancy and community functions; this has influence on the organization of universities.

- The influence of hierarchical management in relation to collegial management is less strong in comparison to the situation in secondary education.

- The influence of peer review is relatively important.

In such a higher education context, terms like 'interventionist' and 'enactment' seem inadequate as primary characterization of faculty-based design, realization, implementation, use and evaluation of digital learning resources.

For these reasons, it is of interest to explore the possibilities of an alternative design-related research paradigm for faculty-based research in higher education. This requires elaboration and articulation of such a paradigm, in particular with a focus on what to publish.

\section{Defining Design-Oriented Research}

One of the design-related research approaches is 'information systems design science research'. Against the background of the 'scholarship of teaching' and the fact that digital learning resources are essentially information systems, it is relevant to point out that in information systems design science research much attention is paid to communication. Peffers et.al. (2007) discuss a number of case studies in which communication involved publication in peer-reviewed scholarly journals or refereed conference proceedings. Such publications are the basis of the claim that their methodology aims to be a research methodology. It differs from design because "A design artifact, ... is not necessarily required to embody new knowledge that would be conveyed to an audience through a scientific publication outlet." (Peffers, et. al., 2007). Such a view on design and on research methodology would include a category of faculty-based efforts to design, realize, implement, use and evaluate learning resources and to share knowledge, by means of publications that 
are reviewed by peers. Moreover, it makes sense that this category inherits its name both from design as well as from research. In this article, design-oriented research (DOR) is defined as research that primarily aims to produce an innovative design, applies typical concepts of design methodology and contributes to a knowledge base, not only in terms of (realized) designs but also in terms of scientific publications.

Publications on 'Design and Evaluation' where evaluation is goal-based evaluation (see Verschuren \& Hartog, 2005) would typically fall within our definition, but many publications with a design-oriented flavor have titles that do not directly refer to design and/or to evaluation.

The definition of design-oriented research that used in this article implies the following research questions.

- What are, in a specific real life context, goals that make sense and why?

- How can these goals be articulated in terms of measurable quantities?

- Is it possible to achieve these goals?

- If so how?

The publications listed in the beginning of this introduction mostly fit the intention of the DOR definition. While not all aspects of the generic DOR question are answered in each publication, the publications together help to articulate a design-oriented research methodology for facultybased research projects on digital learning resources.

\section{A Model of Design that Transcends Disciplinary Boundaries}

Literature on the design of learning resources tends to be published in disciplinary journals and to stay within one discipline. However, many practical design challenges, do not fit within one discipline. For this reason, this subsection describes a constraint-based model of design that is an abstraction of what can be found in a range of disciplines.

Constraints are very dominant in the design literature in many disciplines. Many authors model a constraint $\mathrm{C}$ (implicitly or explicitly) as a relation on the domains of a sequence of quantitative and/or qualitative variables (Borning, Freeman-Benson, \& Wilson, 1992; Gross, 1985, Gross, 1988; Kuchcinski, 2001; Ohlsson \& Mitrovic, 2006; Simon, 1996; Wallace, Philpott, O'Sullivan, \& Ferris, 2006). Here, the domain $D_{i}$ of a variable $x_{i}$ is the set of its possible values $\left\{a_{i, 1}, a_{i, 2}, a_{i, 3}\right.$, $\left.\ldots a_{i, m}\right\}$. The domains of $n$ variables define a Cartesian product $D_{1} \times D_{2} \times \ldots \times D_{n}$. A constraint $C_{i, j, k, \ldots}$ defines a subset of $D_{i} \times D_{j} \times D_{k} \times \ldots$. In this model of design, a design goal is defined in terms of constraints, variables and values. These define a design space.

Parts of the design space might be considered to be within a specific knowledge domain or be 'managed' or 'covered' by a specific discipline. Some constraints might be within one knowledge domain or a part of the design space that is covered by one discipline. However, many constraints will cross artificial boundaries that have been determined by the evolution of disciplines. This also holds for several requirements on the design of digital learning resources in higher education. Some requirements may be almost exclusively related to learning of students and to captivation of students' attention. Other requirements might be primarily organizational constraints, budgetary constraints, constraints of information systems infrastructure, practical constraints of available expertise and capacity etcetera. In practice, many variables will be in more than one knowledge domain. A design goal in such a constraint-based model of design is a subspace of the design space and is defined by constraints. Here design requirements are a special class of constraints. Four important classes of constraint generators are legislators, users, clients and designers (Lawson, 2006). 
In such a model of design, a goal to be achieved is a subspace in a design space. In a FB DOR project on digital learning resources this subspace will intersect with several knowledge domains. For simplicity such a goal can be described as having several goal-components (Hartog, et al., 2010). Examples of goal components are: a learning component, a motivational component, an organizational component, a financial component, an interoperability component, et cetera. Here the term 'goal-component' refers loosely to a set of constraints. The terms 'for simplicity' and 'loosely' are used because a set of constraints that make up one 'goal-component' will not be isolated from the other sets of constraints.

\section{Output-Classes}

\section{Output-class 1: Design Goals and Operationally Defined Design Requirements}

FB-DOR for digital learning resources implies that project activities aim to achieve a design goal and that evaluation aims to test if the design goal indeed can be achieved with the realized digital learning resources. In FB-DOR a design goal usually is composed of various goal components. Some of these may be directly related to student learning. Examples of such goal components from some WU projects are listed here.

- Promote active acquisition of Food Chemistry knowledge (Diederen, Gruppen, Hartog, Moerland, \& Voragen, 2003).

- Support students in acquiring a certain level of understanding of a specific concept (Busstra, Hartog, \& van 't Veer, 2005).

- Support students to achieve a specific new learning goal (Aegerter-Wilmsen, 2005; Aegerter-Wilmsen \& Bisseling, 2005; Aegerter-Wilmsen, Bisseling, \& Hartog, 2003; Aegerter-Wilmsen, Janssen, Hartog, \& Bisseling, 2005; Aegerter-Wilmsen et al., 2006; van der Schaaf, Vermue, Tramper, \& Hartog, 2003; Sessink, Beeftink, Tramper, \& Hartog, 2006; Wilmsen, Bisseling, \& Hartog, 2002).

- Support students in learning a structured approach to specific classes of modeling problems (van der Schaaf, Tramper, Hartog, \& Vermuë, 2006; van der Schaaf, Vermuë, Tramper, \& Hartog, 2006).

Two remarks have to be made with respect to examples like these. Firstly, these goal-components actually refer to functional requirements of the learning resources. Secondly, these goalcomponents refer to goals to be achieved within a small piece of discipline-specific education within a course context. Curriculum goals might provide constraints on the design of such a small piece of education. This is an aspect of 'alignment' of detailed learning objectives and high level curriculum goals (Biggs \& Tang, 2007).

Not all goal-components will be directly related to a learning objective. For instance, a component of a design goal might consist of a set constraints that involve the teaching load of instructors using the learning resources, or a set of constraints that involve the motivation of students to allocate their attention to certain specific challenges.

\section{In DOR overall design goal formulations change over time}

Overall design goal formulations may change considerably during the time of the project. At the start of an innovative design process, it is usual to formulate an overall design goal. This is necessary to get support of stakeholders and to give some rough indication of the direction in which the process must evolve. In some projects the design goal can be quite clear from the start, at least 
within a population that shares a body of common values and knowledge. For instance, the goal to 'put a man on the moon' is quite clear to many people. In practice however, the formulation of design goals is often not so clear and needs to be articulated and adjusted later on. One reason is that the knowledge and terminology to define the intentions of the design process are seldom available at the start of the project. A second reason is that innovative design is a process of constraint exploration. While some constraints might be clear from the start, innovative design means that many constraints will have to be found and expressed during the project (Gross, 1985; Jonassen, 2008). This implies that a goal as defined by a final constraint set is output rather than input of the corresponding innovative design project. A third reason is that overall formulations of a design goal or goal-components are seldom adequate for determining if these goals have been achieved at the conclusion of the design process. The examples of 'goal components related to student learning' listed above make this very clear. Thus, it will be necessary to produce operationally defined design requirements and to reformulate the overall design goal.

\section{Operationally defined design requirements}

Operationally defined design requirements define the actual goal of the design process. Such requirements make explicit how one can observe or measure if a design goal has been reached.

In some design challenges, the mapping from design goal to operationally defined design requirements can be the result of a process that starts with the design goal and successively further articulates this goal. In other design challenges, design goals are actually some form of abstract aggregation of a set of operationally defined design requirements. Thus, in innovative design, the most adequate formulation of the design goal will often appear late in the design process.

In DOR, the mapping from design goals to operationally defined design requirements for learning resources cannot be derived by pure logic inference. Defining this mapping involves empirical research, decision-making and corresponding argumentation. In the field of information systems design, this is becoming more and more acknowledged (Gilb, 1997; Glinz, 2005; Lamsweerde, 2001; Sommerville, 2007). This is also in keeping with the idea of design as constraint exploration in combination with the view that requirements are a special class of constraints.

\section{Relationship with learning goal-components and assessment}

In the remainder of this article the term 'learning goal-component' will be used to refer to a set of constraints on performance indicators for whatever has to be learned.

The operational definition of the learning goal-component should define what actions by the student would count as demonstrating that the student has achieved a certain aim and be sufficiently precise in order to come to agree with peers about whether a student has achieved the aim (see Laurillard, 2002).

In this article the term assessment refers to observing the actions and assigning values (qualitative or quantitative) to performance indicators and comparing results with criteria.

Ideally, the operational definition is based on a measuring or observation instrument. Such an instrument can be used in assessment. Concept inventories (e.g. Ding, Chabay, Sherwood, \& Beichner, 2006; Garvin-Doxas \& Klymkowsky, 2008; Hestenes, Wells, \& Swackhamer, 1992; Klymkowsky \& Garvin-Doxas, 2008; Klymkowsky, Garvin-Doxas, \& Zeilik, 2003; C. D. Wilson et al., 2006) can be considered such instruments. These instruments are highly subject matter specific. They require primarily or exclusively input of faculty.

A constraint in the definition of the design goal for digital learning resources can specify a requirement as to the percentage of students in a case study that achieve scores in a predefined set based on measurements or observations with an assessment instrument. In practice, such a meas- 
urement or observation instrument is often not available. Often one settles for a panel of experts. Often these are required not only to observe or measure, but also to provide an interpretation of the results and a rating. A discussion of inter-rater reliability is beyond the scope of this article.

\section{Operationally defined requirements in WU projects}

In only one of the WU projects (Sessink, Beeftink, Tramper, \& Hartog, 2007) a set of closed questions for cell growth kinetics was developed. This set of questions can also be regarded to constitute a measuring instrument. However, in the other WU projects no such instrument was part of the output of the research. In most of the projects open exam questions were formulated and published or described in the corresponding publications. In some WU projects, students had to submit a report (van der Schaaf, 2003; van der Schaaf, 2006). However, in several publications, the authors did not specify criteria that discriminate categories of answers. In other words, they did not share precise definitions of required actions and/or answers with peers. This is in line with the current practice of very much assessment in higher education as well as in the academic system of peer review. Consequently, in the current practice of FB-DOR, those operational design requirements that make up the learning goal-component are likely to be linked to a specific set of teachers.

For goal components that were less directly related to learning, several operationally defined design requirements in the WU projects were related to motivation of students and to efficiency of studying.

Finally, there might be requirements that refer to the technical and organizational context in which the resource will have to be managed. For instance, an operationally defined requirement might be that the interface of the resource conforms to the SCORM 2004 specification (ADL, 2006).

\section{Concluding remarks with respect to output-class 1}

Evaluation of output in output-class 1, will at least concern the mapping between a goalcomponent and its operationally defined design requirements. The description of this mapping should be evaluated by other designers and stakeholders (Verschuren \& Hartog, 2005). For the learning goal-component, this comes close to traditional content validation as described in traditional assessment literature (Gronlund, 1965). Inspiration for evaluation approaches can also be found in concept inventory publications. In higher education, such evaluations are primarily the task of university professors who teach the subject matter (Lundvall, et al., 2000).

In FB-DOR on innovative digital learning resources both the design goal and the operationally defined design requirements represent new knowledge and form a class of outputs of the DOR process. These outputs are reusable and satisfy the utility requirement for outputs that is highlighted e.g. in (Hevner, et al., 2004). Thus, it makes sense to submit these outputs for peer review and to publish them.

Insofar subject matter related design requirements can be represented in the format of a scientific journal it makes sense to publish them in journals that are read by university professors in the relevant subject matter disciplines. These are journals of the discipline and discipline specific education journals. Thus, DOR on learning resources would benefit from a publication culture that acknowledges the value of sets of operationally defined design requirements in terms of assessment tasks. In other words, typical exam questions and descriptions of new types of assessment and their underlying design rationale should in principle be considered worthy of publication (see for instance Schönborn \& Anderson, 2008). 


\section{Output-class 2: the Abstract Representation of the Design}

\section{Introduction}

A second output of a design process should be 'the design'. Ideally, 'the design' is a model of what has to be realized. A model is described in an adequate representational formalism. In Figure 1, the term 'blueprint' is used for short. Indeed, for a house or a building, the description is a blueprint using a representational formalism based on a set of symbols for components like doors, windows and walls, and relations between components. For airplanes, ships, information systems or music, other sets of symbols are available. Of course, the physical realization of the design (e.g. the house or the ship or a realized learning scenario) is also a representation of the design.

\section{The abstract representation of a design}

Design-oriented research should ultimately result in one or more designs that can be submitted for review in a scientific community. A submitted design will be represented in some abstract form or by means of its realization. Both can be valuable products of a design process. In this section, we argue that the abstract representation should be acknowledged as such in its own right. In fact, reviewing of scientific products that are represented in an abstract formalism is in line with what is common practice in a range of scientific disciplines, in particular in mathematics but also in many engineering disciplines. It is less common in journals in the fields of education. Digital learning resources are essentially information systems. In information systems literature and in software engineering, it is quite generally acknowledged that abstract models are valuable for the purposes of communication, highlighting aspects, postponing expensive work and for documentation (Borgida, Brachman, Coombs, \& Sowa, 1991; Chen, 1976; Dennis, Wixom, \& Tegarden, 2005; Hevner, et al., 2004; Österle, et al., 2011). However, for digital learning resources, we do not yet recognize a publication culture in which it is normal that an abstractly represented design can and should be submitted for review.

In the next subsection we argue why there are benefits of having a publication culture in which it is acknowledged that a blueprint without a corresponding realization (e.g. an information system that is not yet realized), merits its own reviews. For such reviews, the actual realization is not required.

\section{Why abstract representations of a design should be considered as potentially valuable and valid output of DOR}

Abstract representations of a design support communication between people with different roles and different disciplinary backgrounds. Abstract representations function also as documentation that can be studied in later times and other locations.

In particular, abstract representations support highlighting different subsystems of the design. For instance, in the blueprint of a building one can separately highlight the model of the plumbing or the model of the electrical system. In the abstract representation of most information systems, one can separately highlight a model of the database and a model of the user interface. Abstract representations also support the structuring of discussions and can make argumentation transparent.

Note, that this does not require an empirical evaluation of the operation of the realized design.

Finally, abstract representations of a design are a basis for analysis of the costs and benefits of implementing and operating the realized design, for assessing related risks and for planning the realization. In particular, in cases where realization, implementation and setting into operation of the design are expensive and/or imply high risks, review of the abstract representation is essential. Examples are the design of a nuclear waste facility, an information system for making flight res- 
ervations or a new law that defines a nationwide education policy. Even in cases where risks are less high, it often makes sense to review the abstract representation of the design before one invests in realization, implementation, setting into operation and empirical evaluation.

Thus, we argue that, with respect to design and realization of digital learning resources, it is desirable to initiate a shift toward publishing abstract representations of designs. This requires representing 'blueprints' of learning resources that are suitable to be reviewed by reviewers of the most relevant journal and, if they satisfy the standards set by the journal, published accordingly. However, given the practical limitations of journals, it will usually only be possible to accept descriptions of general architectures and descriptions of interfaces. In the next two subsections we elaborate architectures and interfaces and provide illustrations for digital learning resources in higher education.

\section{Output-class 2a: the architecture of a design}

An important result of a process of designing a system such as a building, an information system, a body of learning material or a national educational system, is a top-level structure and a set of related overall characteristics. In information systems design, such a top-level structure is called 'an architecture'. While a system can be composed of many sub-systems, its functionality is in general intended to be more than the sum of the functionalities of the subsystems.

The architecture of a system is a component of the design. In most design disciplines, the architecture is considered as an output-class by itself. Examples of architecture publications in the field of information systems for learning support can be found in (Baghaei, Mitrovic, \& Irwin, 2006; Bouras \& Tsiatsos, 2006; Brusilovsky, 2004; Deek \& McHugh, 2003; Ferdig, Mishra, \& Zhao, 2004; Gütl et al., 2005; Hiddink, 2001; Jara et al., 2009; Nijholt, 2006; Paulsson \& Naeve, 2006; Rosé, Roque, \& Bhembe, 2002; Sampson, Karagiannidis, \& Cardinali, 2002; Sampson \& Karampiperis, 2006; A. Schmidt \& Winterhalter, 2004; Sessink, Beeftink, et al., 2007; Sheremetov \& Arenas, 2002; Sierra, Moreno-Ger, Martínez-Ortiz, López-Moratalla, \& FernándezManjón, 2005; Wilson, 2005).

For learning resources, learning environments and more generally for highly interactive information systems, we propose to distinguish an 'external' architecture, i.e. the main structure of the user interface and an 'internal' (or system-) architecture. This system architecture should both enable providing the user an overall experience that fits the design goal, as well as efficient realization and maintenance of the system taking into account requirements of modifiability, performance, security, availability and reliability (see Clements, Kazman, \& Klein, 2002).

ICT allows us to separate the former architectural aspects from the latter. For instance, a set of learning objects (LO's as described in the next section) might internally be stored in a relational database. For different target populations the system might present different 'external architectures'. For instance, based on the same 'internal technical architecture' the system might present on the screen different hierarchies or different preferred learning path's to members of different target populations.

\section{Illustrating external architectures}

The 'external' architecture of a digital learning resource will usually be related to one or a few overall types of learning goals. The 'external' architecture of many designs resulting from the WU projects was the result of combining cases with a hierarchical view of a library of learning objects and sometimes a glossary and an index to formulas and symbols.

A case is a combination of a situation, an assignment and a role for the student. Examples of such a role for the student were 'assistant of the lab instructor' and 'consultant'. In such a role, the student had to complete an assignment. This generally required the student to make series of deci- 
sions and to answer questions. The student could anytime revert to a relevant presentational learning object (LO) in the library by following a link from within the case or by entering the library directly. Presentational LO's are LO's that present information in terms of texts, diagrams, screen-recordings and animations.

In general, an external architecture is intended to match a vision on society, business processes, knowledge management, learning and so on and so forth. The external architecture designed for many of the WU projects was intended primarily to support the vision that students should learn specific tasks such as the task to design a purification line (van der Schaaf, et al., 2003) or a specific type of experiment (Aegerter-Wilmsen, et al., 2003; Busstra, Hartog, Kersten, \& Müller, 2007; Diederen, Gruppen, Hartog, \& Voragen, 2006) or the analysis of data from human intervention trials or observational studies in human nutrition research (Busstra, Geelen, Feskens, Hartog, \& van 't Veer, 2008). The external architecture is matched with the vision that students can learn such tasks to a great extent by carrying out analogous tasks in a virtual environment. In addition, it was supposed that learning the actual task can be supported by providing seamless access to necessary information and automated feedback on the students' actions. Here, seamless access is defined as access that does not by itself impose any cognitive load.

\section{Illustrating internal architectures}

Most learning resources in the WU projects fit the following 'internal technical architecture' description:

- A database containing reusable presentational LO's.

- One or more definitions of an ordering of these LO's. Different definitions enable the presentation of one or more different user views of relationships between LO's. For instance, different hierarchical orderings may be applied to present different library structures. One library structure might be intended to highlight the structure of the disciplinary knowledge. Another library structure might be intended to suggest a preferred learning path for novices.

- Cases that are constructed of interactions. Interactions allow the learner to interact with the LO or module. Through an interaction, the student selects or constructs a response. The interactions are conceptually the same as the interactions defined in the QTI 2.0 specification (Sessink, van der Schaaf, Beeftink, Hartog, \& Tramper, 2007). Depending on the learners' response in a certain interaction a new instance of one of the available interactions is presented to the learner.

- An author-defined data storage that enables storing and processing of student's responses (Kassahun, Beulens, \& Hartog, 2006; Sessink, Beeftink, \& Hartog, 2005; Sessink, Beeftink, Tramper, \& Hartog, 2003).

- A database of definitions and formula's that supports on-demand presentation of information for instance in the form of pop-ups.

- A simple design and/or experiment environment that enables the student to design models and to run virtual experiments.

\section{Concluding remarks about publishing architectures of a design}

An architecture can be regarded from different viewpoints. In particular (Clements, et al., 2002)

- as a vehicle for communication among stakeholders

- as the manifestation of the earliest design decisions 
- as a reusable transferable abstraction of a system.

Exposing such a top-level structure and the underlying decisions and their arguments in publications is important and quite common in many disciplines. It makes sense that such top-level structures become accepted as potentially valuable and valid output in FB-DOR as well.

\section{Output-class $2 b$ : interface definitions}

The interface of a system describes a set of assumptions about the inputs or the environment of the system and a definition of the output(s) or the function(s) of the system.

For systems that can be replaced by other systems without the need to impose new requirements on the outer environment the term module is very common. The concept of interface is the basic concept that is used to realize modularity.

In instructional design, modular approaches have been described long ago in (Romiszowski, 1984; Russell, 1974). A special class of learning resources is the class of digital learning resources. Modules of digital learning material have been called 'units of learning material', 'learning objects' or 'reusable content objects' (Collis \& Strijker, 2002; Duval, 2005; Duval, Hodgins, Rehak, \& Robson, 2004; ESCOT, 2001; Koohang, Floyd, \& Stewart, 2011; Moonen, 1999; Roschelle et al., 1999). Here the term Learning Object (LO) refers to modules of digital learning material with one or only a few functions and few assumptions with a small scope. For instance one might construct a LO that has only one function. An example of such a function could be "to present to the student what the Polymerase Chain Reaction (PCR) is". Another LO might have as its sole function to present to the student for what purpose the PCR can be used. Yet another LO may have as its sole function to let a student experience something that can easily go wrong in using PCR. An LO is essentially a self-contained information system.

Modules and Learning Objects are defined by their interfaces. In innovative design, each interface definition of a module is an output of design-oriented research. We argue that interface definitions should be acknowledged as such and that interface definitions should be submitted for review and publication. In information systems design, a coherent set of interface definitions is already considered sufficiently valuable output of a design process. Such a set of coherent interface definitions can be reviewed, i.e. requires inspection by peer reviewers. It must be noted however, that the peer review process of interface definitions in engineering sciences, for instance in the field of information systems, usually takes place in working groups within professional organizations (ADL, 2008; IEEE, 2008; IMS Global Learning Consortium, 2007). Academics take part in the development and review of such interfaces, but in cooperation with industry. Moreover, the bulk of the results of these defining activities is not published in academic journals. Such phenomena have also been signaled in (Gibbons, 1999, 2002; Gibbons et al., 1994; Ziman, 2002). The interface definitions are peer-reviewed and public, but usually in reports or specifications and not in journals.

\section{Concluding remarks about interfaces}

In line with this, we argue that an innovative set of interface definitions of a learning modules or learning objects should be regarded as potentially valuable output of a design process. Such an interface should for instance include a description of the prerequisite knowledge. In fact, to a large extent, a specification like the IMS learning material meta data specification (IMS, 2006) already indicates what should be part of the interface description of a learning resource. Publishing interface definitions in peer-reviewed scientific journals as output of design-oriented research also makes sense. Once a scientific community accepts the potential value of interface definitions, this community should also provide opportunities for review and publication. If not, the community creates a barrier for scholars to invest efforts in defining interfaces. Finally, it should 
be noted that an interface can best be judged based on its description. Realization of the corresponding design is only relevant for the review of the interface insofar there may be doubt as to the feasibility of realizing an artifact that technically implements the interface.

\section{Output-class 3: Learning Scenarios}

A learning scenario is a design of a process. A learning scenario defines roles for all actors and for learning resources in a teaching-learning process or just a learning process. Furthermore, the scenario may define which actions are planned and what constraints are imposed on the set of possible orderings.

A good example of a learning scenario that has been designed decades ago and was quite innovative at the time is 'problem-based learning (PBL)' (Gijbels, Dochy, Van den Bossche, \& Segers, 2005; Moust \& Schmidt, 1998; H. G. Schmidt, 1983). Point of departure in a PBL process is a short description of an intriguing problem. Part of the activities in a PBL process are discussions in groups of about 10 students. Students analyze the problems, formulate learning goals, consult external sources of information (partly in self-study setting) and reconvene to report their results. A tutor coaches the group discussions.

Another well-known learning scenario is the lecture. In a real lecture, the lecturer lectures and the students listen to the lecture and try to process what the lecturer presents and to make notes. Variations on this type of scenario include the lecturer asking questions to the audience and/or the students asking questions to the lecturer. The lecture can be based on or supported by learning material that is purely presentational. This is the most common lecture scenario. Alternatively, a lecture can be based on a virtual experiment environment. In such a scenario, the lecturer can ask questions or stimulate the students to ask questions with respect to configuring an experiment set up, setting parameters and expected experimental outcomes. In such a scenario, the lecturer and the whole group work together towards a satisficing design of the experiment. The lecturer leads the discussion, and students propose actions within the design environment, virtual experiment environment or modeling toolset. The lecturer performs these actions, for example making connections between unit operations, and shows intermediate results on a large screen in a lecture room. In another learning scenario, the same tool might be used by students who work on an individual basis. Again, the goal would be that the student learns to design and carry out experiments given a certain need for information.

One learning scenario can often be realized with several different learning resources and one module of learning material might be used in different learning scenarios. Again, this can be compared with a textbook. Textbooks are used in a wide range of different learning scenarios.

In most of the WU projects, one of the design requirements was that the overall learning scenario should not enforce a learning scenario on teachers and students. The reason for aiming at learning material that is useful in a range of learning scenarios was that the material was intended to be useful in many universities. Thus, possible matching learning scenarios should not be restricted to those that are used at a specific university.

In general, we would say that in the WU projects, no innovative learning scenarios were designed, thus no examples of WU publications in this output-class can be given.

\section{Output-class 4: Realized Designs}

An obvious class of candidate outputs of a design process is the class of realized designs. Often a realized design is the realization of an abstract representation of a design. For instance the actual construction of a building based on its blueprint. Another instance of a realized design is a learning object based on a storyboard and a set of interface definitions. 
Alternatively, a realized design can be a direct realization. This means that there is no abstract representation of the design proper. There is a house but no blueprint. Currently, most digital learning resources, including those resulting from the WU projects, are direct realizations.

A realization of a design is seldom fit for publication in a journal. For instance, a real building does not fit in a journal. Neither does a piece of digital learning material. Nevertheless, the realized design of a learning resource or coherent body of learning resources should be considered as a candidate output of design-oriented research and a potential contribution to the growth of pedagogical content knowledge. It must be possible to submit these outputs to the scientific community for review. Currently a design-oriented publication in a scientific journal usually only contains a pointer to a realized design instead of the realized design itself. Examples of such pointers are descriptors of the physical location of a building or a web address of a learning object. In practice, the characteristics of the realized design often seem to bear little weight in the review process of the corresponding article about the realized design.

One problem is that few subject matter experts make themselves available for review of realized designs. There have been some attempts to set up review processes for LO's in several projects (Cafolla, 2006; Harrigan, Carey, \& Ld Team, 2005; Smith-Gratto, Wicks, \& Berger, 2002).

However, there is not yet an established practice of publishing realized designs of digital learning resources that includes a scientific refereeing process. Furthermore, publications about digital learning resources are often not yet directly linked to reviewed and published digital learning resources. We propose that reviews of publications about realized designs are accompanied by review and publication of the realized designs themselves. This should hold in particular for printed or digital learning resources, because for these products access can be realized at low costs. The possibility to access and use innovative digital learning resources by any lecturer at any university would also enable attempts to reproduce empirical evaluation results.

\section{Output-class 5: Case Study Results}

\section{Output-class 5a: a record of an implementation}

'Implementation' is : fitting the realized design into its outer environment. Here, this refers to faculty fitting digital learning resources in a course that they teach.

The design of a system is based on assumptions with respect to the outer environment. These assumptions are at the same time requirements to the outer environment of the realized design. It often occurs that these assumptions turn out not to hold any more, by the time we try to fit the realized design in its environment. In other words, that the requirements as to the outer environment are not satisfied. In such a case, additional changes in the outer environment may be needed. Such changes may require considerable efforts. In order to reduce the risk of expensive implementations it is quite usual to design a product in which a number of parameters can be set at implementation time. In such a case, implementation involves setting the operating parameters of the realized design. For an electrical appliance this might be: setting a switch from 230 volts to 110 volts. An example of an operating parameter for a learning object might be a parameter that determines the language. Thus, implementing the learning object might involve setting its language from English to German or Arabic. Implementing a learning object using a learning scenario involves among other things realizing access to this learning object. If the learning scenario includes a role for an instructor, then implementation also involves preparing the instructor for this role.

We argue that a record of the implementation process of an innovative artifact can be a valuable output of FB-DOR in education. In particular, a list of those assumptions in the interface that did not hold and a list of the succeeding adjustments that were made, are likely to contain important 
information. An example of an implicit assumption that turned out to be wrong in the WU projects is the following.

One of the design requirements for digital learning resources in WU projects was that the resources can be implemented and used in a wide range of different learning scenarios in different universities. Indeed faculty of several different universities implemented WU digital learning resources in their courses, some in slightly different learning scenarios. These implementations at least revealed one set of implicit assumptions that repeatedly turned out to be incorrect. Implicitly it had been assumed that material after one successful trial at a test site would automatically be used more times at that test site. In practice, continuation of use after initial successful use, turned out to be an unexpected problem. Moreover, it has not been possible to attribute discontinuations to one common factor. Sometimes, the next year a new staff member was assigned to the course in which the material was used. Sometimes, local changes in the organization of the ICT infrastructure led to a failure at an inconvenient moment. Sometimes a lecturer asked too late for allocation of ICT facilities and so on and so forth.

Usually, publications of case studies do not clearly distinguish the implementation process from the other parts of a case study. We propose that a record of an implementation process is acknowledged output of DOR. An article that presents a case study of the use of a digital learning resource or coherent body of learning resources should contain at least a separate section dedicated to a description of the implementation process. This section should contain a list of the assumptions that did not hold and a description of the adjustments that were needed. Furthermore, such a section should list implicit assumptions that were revealed at implementation time. On the one hand the record is necessary for a correct interpretation of the data collected in the case study. On the other hand, falsification of some assumptions might be knowledge that is valuable not only within the project but also outside the project.

\section{Output-class 5b: a record of observations and measurement results of a realized learning scenario}

A learning scenario defines roles for all actors and for all other educational resources; in addition the scenario may define which activities and actions are planned and in what order. In the WU projects, tools, design environments, modeling environments, virtual experiment environments and cases have been designed and developed such that they could be used in different learning scenarios. Except for one system that is described in (Sessink, Beeftink, Tramper, \& Hartog, 2007), all these tools, environments and cases can be used in a regular classroom in a group discussion scenario as described above. Both the plan for the scenario and the underlying arguments as well as the record of its execution should be standard sections in publications of case studies about the use of digital learning resources. Without a description of the role that the realized design has played in the learning scenario the "if so how" research question will not be sufficiently answered.

\section{Output-class 5c: proof of feasibility}

When a design is realized and implemented in a certain context (outer environment) and has been put in operation, the operation can be studied in a case study. A case study can answer the question if it is possible to satisfy all constraints (including all requirements) in practice. If it has been demonstrated in one case study that the realized design in operation has satisfied all constraints, this means that it has been possible to achieve the design goal at least once. Note that the goal should not be envisioned as a point. Rather, the goal is almost always a large set of points in a design space. This set of points is defined by all constraints, including design requirements, laws of nature and human behavior as well as the budgetary limits. The statement 'the goal has been 
reached' thus means that a member of the set of points that define the goal in design space has been reached. In other words, the case study has provided a proof of feasibility.

A proof of feasibility is essentially a falsification of an impossibility hypothesis. This hypothesis would state that it is not possible to design, develop, implement and operate a design that satisfies all constraints. Well-known proofs of feasibility are the first aircraft flights with human beings and the first arrival on the moon. A literature search across many disciplines provides many research publications presenting proofs of feasibility (for instance in surgery or in engineering sciences). We consider a proof of feasibility of achieving a design goal related to a specific body of digital learning resources in higher education to be a contribution of pedagogical content knowledge. The primary intended output of a case study in FB-DOR should be a proof of feasibility. We found it surprisingly difficult to find publications that explicitly report some proof of feasibility, however most of the publications listed in the introduction of this article did implicitly suggest a proof of feasibility. Both from a viewpoint of knowledge management as well as from a viewpoint of scholarship of teaching and learning such proofs should be published and scrutinized.

\section{Output-class 5d: proof of concept}

We define a proof of concept as consisting of (1) one or a few explicitly described concepts, (2) a proof of feasibility, (3) an explanation that links the proof of feasibility to the concept(s) in a satisfactory way and (4) the absence of alternative plausible explanations. In particular, (3) and (4) are subject to expert judgment.

The flights of the Wright brothers (Eckert \& Clarkson, 2005) were proofs of the concept of the combination of artificial wings, propulsion by a propeller and power delivered by an internal combustion engine. Note, that, if the goal is simply 'to fly hundred yards' a completely different concept such as the 'Zeppelin concept' (i.e. floating in air of a shape that is lighter than the air it replaces) can also be proven to 'work'. This does not reduce the value of the proof of concept delivered by the Wright brothers. A proof of concept does not require that there is only one design with which to reach the goal.

In engineering journals, it is not unusual to claim a proof of concept. For certain engineering goals, a small set of simple arguments can link empirical evidence that the design goal has been achieved to the conclusion that this goal achievement can be attributed to a specific concept. Thus, for faculty in engineering sciences, it might feel 'natural' to aim for a 'proof of concept'. In journals in various fields of education the term 'proof of concept' is seldom used, although sometimes a suggestion of some sort of 'proof' is implied.

In case of some devices that have to perform only one or a few functions, the chain of inference from proof of feasibility to proof of concept may be perceived as straight forward and quite simple. However, if the design goal involves many variables and constraints that are not part of the concept, the arguments underpinning the attribution of a specific concept to goal achievement will be primarily theoretical. For instance, attributing goal achievement in case studies with the Proteus system (Sessink, Beeftink, Tramper, \& Hartog, 2007) to its core concept is not trivial. The Proteus system is a system that selects certain questions to be presented to the student from a database of questions. Within Proteus, a model of the students' knowledge that represents a certain distance to a learning goal is updated whenever the student responds to a question. That model determines which questions can be selected next. The core concept of Proteus is comprised of the structure of the model of the students' knowledge, the update algorithm and the selection criteria. Given a goal that the student has achieved with the Proteus system, attributing such achievement to the core concept will imply separating the contribution of the algorithm from 
many other potential contributions. Examples of such other contributions are the quality of each question in the database and the quality of the user-interface.

Finally, there may be other reasons not to claim a 'proof of concept'. In practice, a design can be based on too many concepts for the term 'proof of concept' to be informative. Also, the design goal may be defined in terms of variables and constraints that involve knowledge from knowledge domains that do not fit within one discipline (e.g. 'economy' and 'education'). In such cases, attributing goal achievement to specific concepts will involve handling of differences in vocabularies and methods as well.

\section{Output-class 5e: paradigm example}

A theory requires paradigm examples in order to clarify the meaning of variables and parameters and laws (Kuhn, 1973). Paradigm examples in DOR clarify the meaning of laws or guidelines, which are provided by theory.

For instance many authors promote learning situations in which the learner is active while learning (J. R. Anderson, 1995; Biggs \& Tang, 2007; Collis \& Moonen, 2001; Koper \& Bennett, 2008; van Merriënboer, 1997; Nonaka \& Takeuchi, 1995; Polanyi, 1969). Many authors provide additional constraints on learning or teaching-learning activities. Examples are constraints with respect to a trustful climate, relevance of the task, connection to prior knowledge, possibilities for reflection (Biggs \& Tang, 2007) communication and collaboration (Collis \& Moonen, 2001) and a 'whole task' analysis (van Merriënboer \& Kirschner, 2007). Even then, paradigm examples are needed to give meaning to the term 'activity' in the context of specific subject matter and specific learning goals and objectives. As such, most of the learning resources realized in the WU projects clarify in considerable detail what type of activities are deemed important by subject matter experts in the corresponding disciplines. FB-DOR can and should evaluate and report about 'incontext-applicability' and -usefulness of design guidelines that are delivered by educational research and cognitive science. Arriving at a design that is compliant with such design guidelines is seldom a trivial operation. One reason why formulating and achieving design goals for digital learning resources in higher education is much more than just applying such design guidelines, is that the design requires input of subject matter knowledge by an subject matter expert from a specific disciplinary field. This is one of the reasons why DOR of learning resources is not 'applied research'. Another reason is that in practice, many constraints have to be explored which are not inherent in the instructional design guidelines (Jonassen, 2008). Therefore, paradigm examples that illustrate the relationship between specific content, subject matter, concepts or phenomena within a specific scientific field and the educational or instructional design guidelines can be of great value in educational practice (Larkin, Scheftic, \& Chabay, 1990).

In relation to FB-DOR, paradigm examples should be informative because they clarify theory and because of their success in one or more case studies. Such paradigm examples should demonstrate a possible way to elaborate concepts from a general theoretical framework for specific subject matter.

\section{Concluding remarks about case study results}

A case study should not be regarded as a sample from a population in the statistical sense (Yin, 2003). A proof of feasibility or a proof of concept is valuable in itself and valuable as a starting point for incremental improvement. Aiming at a proof of feasibility or proof of concept is not the same as aiming for general applicability of a design. The more accessible the details of a design and a proof of feasibility or proof of concept, the better it will be possible to reuse the knowledge that is implied by this design and the case study. Various implementations of the realized design in different contexts (outer environments) are likely to require different parameter settings and 
changes in each context as well. The less the design is dependent on assumptions about the context the more likely the design will also 'work' in different outer environments.

Follow-up research aimed to exclude alternative explanations or to provide more empirical evidence for proof of concept claims or aimed to investigate if the design works in a range of related contexts should be classified as design-based research or developmental research and requires another (i.e. not DOR) research mode.

\section{Design Patterns: a Borderline Output-Class}

The concept of Design Pattern has been introduced by Alexander and Ishikawa (1977) in architecture. Later, design patterns were adopted in other fields such as software engineering (Gamma, Helm, Johnson, \& Vlissides, 1994) and more recently in the field of learning and instruction (Baggetun, Rusman, \& Poggi, 2004; Cristea \& Garzotto, 2004; Derntl, 2004; Dimitrova \& Suthcliffe, 1999; Draaijer \& Hartog, 2007; Goodyear, 2005; Mislevy et al., 2003; Underwood et al., 2005)

For different subject matter disciplines, it makes sense to describe design patterns. Some of these design patterns may be recognized in more than one subject matter discipline. An example of a design pattern that can be recognized in WU learning material is the combination of a problem and a set of interactions (Aegerter-Wilmsen, et al., 2003; Busstra, et al., 2007) as follows.

Given the challenge to teach the student to design an experimental procedure:

- Present a set of types of research objects. For instance, if the research question is to find the effects of free fatty acids on gene expression in the liver and which transcription factors are involved (Busstra, et al., 2007), then the types of research objects might be e.g. 'cells'or 'human'.

- For each of these types of research objects, make a further selection of what to study from a set of subtypes or foci or parts. For instance, when the student decides to study humans (given the same research question) he might be presented the set 'liver cells', 'red blood cells', 'blood plasma', or 'urine' to select from.

- For each of these, present a set of treatments or processing steps and let the student select a treatment or processing step. Depending on the actual object that one wants to prepare for measurements and depending on the research question, different treatments or processing steps make sense. For instance, heating, drying, mixing, crossing, fasting, giving a special diet, et cetera.

- Present possible variables to measure and let the student select a variable.

- Present a set of possible measurement techniques for this variable and let the student select a measurement technique.

- Categorize combinations of possible selections. Each category would imply specific feedback. This feedback would be based on what the combinations in the category have in common. For instance, it makes sense to try to define relations between those categories and the concepts that students should learn.

- Provide feedback on each of the resulting categories of combinations.

The example also makes clear that a design pattern itself is often related to specific subject matter. The example of the pattern that is presented here has recurred several times in the learning material in WU projects, but does not yet warrant a claim that it is generic enough to be applied in every science course. 
Insofar design patterns are made explicit in order to structure documentation of the design by highlighting recurrent patterns and help answering the 'if-so-how?' question, they can be regarded as outputs of design-oriented research.

Insofar design patterns are claimed to be reusable in new designs they better fit descriptions of intended output of developmental research (Richey, et al., 2004) or the family of educational design research approaches as described for instance in (van den Akker, et al., 2006b).

\section{Conclusion}

This article aims to contribute to a paradigm of faculty-based design-oriented research (FBDOR). For this purpose it lists, defines and articulates classes of potentially valuable or 'candidate' outputs of FB-DOR in higher education. These output-classes were derived from experience with FB-DOR in natural and engineering sciences and from literature in a range of disciplines. Examples of such outputs in higher education have been given, as well as arguments why outputs of these types should be considered valuable.

Many design-oriented publications in scientific journals describe output that fits some of the listed output-classes. The set of output-classes presented in this article covers at least the union of the outputs of those design-oriented publications. However, we have argued that in publications on digital learning resources these output-classes do not yet receive enough attention. In particular, interfaces and operationally defined design requirements are currently seldom regarded as candidate outputs in the context of the design of particular learning resources. Furthermore, 'blueprints' of digital learning resources are seldom published in peer reviewed journals. Partly, this can be explained by the lack of an adequate representational formalism for digital learning resources. At the same time, realized digital learning resources are in practice also insufficiently subject to peer review. Lack of peer reviews of digital learning resources and their abstract representations can also be attributed to the situation that there are no journals in which the complete set of outputs of an FB-DOR project would fit. The practice is that outputs in different outputclasses will be published in different types of journals.

Finally, an output-class that is not discussed in this article as a separate output-class is the class of evaluation results. With respect to FB-DOR in higher education, this article specifies what categories of outputs should be evaluated and reviewed and why. The question how products in these categories should be evaluated is beyond the scope of this article.

\section{References}

Abell, S. K. (2008). Twenty years later: Does pedagogical content knowledge remain a useful idea? International Journal of Science Education, 30(10), 1405 - 1416.

ADL. (2006). SCORM Retrieved August 15 2012, from http://www.adlnet.gov/capabilities/scorm/scorm2004-4th

ADL. (2008). Advanced Distributed Learning home page Retrieved 2008, from http://www.adlnet.gov/

Aegerter-Wilmsen, T. (2005). Digital learning material for experimental design and model building in molecular biology. $\mathrm{PhD}$, Wageningen University, Wageningen.

Aegerter-Wilmsen, T., \& Bisseling, T. (2005). Biology by numbers-Introducing quantitation into life science education. PLoS Biology 3(1), e1.

Aegerter-Wilmsen, T., Bisseling, T., \& Hartog, R. (2003). Web based learning support for experimental design in molecular biology: A top-down approach. Journal of Interactive Learning Research, 14(3), 301-314. 
Aegerter-Wilmsen, T., Janssen, F., Hartog, R., \& Bisseling, T. (2005). Digital learning material for model building in molecular biology. Journal of Science Education and Technology, 14(1), 123-134.

Aegerter-Wilmsen, T., Janssen, F., Kettenis, D., Sessink, O., Hartog, R. J. M., \& Bisseling, T. (2006). Introducing molecular life science students to model building using computer simulations. Journal of Computers in Mathematics and Science Teaching, 25(2), 101-122.

Alexander, C., Ishikawa, S., Silverstein, M., Jacobson, M., Fiksdahl-King, I., \& Angel, S. (1977). A pattern language : Towns, buildings, construction. New York: Oxford University Press.

Anderson, J., \& DiCarlo, S. E. (2000). Virtual experiment for understanding the electrocardiogram and the mean electrical axis Advances in Physiology Education, 23(1), 1-17.

Anderson, J. R. (1995). Learning and memory : An integrated approach. New York: Wiley.

Anderson, T. R. (2007). Bridging the educational research-teaching practice gap. Biochemistry and Molecular Biology Education, 35(6), 471-477. doi: 10.1002/bmb.20135

Aziz, E.-S. S., Esche, S. K., \& Chassapis, C. (2007). Content-rich interactive online laboratory systems. Computer Applications in Engineering Education, 17(1), 61-79.

Baggetun, R., Rusman, E., \& Poggi, C. (2004). Design patterns for collaborative learning: From practice to theory and back. In L. Cantoni \& C. McLoughlin (Eds.), Proceedings of World Conference on Educational Multimedia, Hypermedia and Telecommunications (pp. 2493 - 2498). Lugano: AACE Chesapeake VA.

Baghaei, N., Mitrovic, A., \& Irwin, W. (2006). Problem-solving support in a constraintbased tutor for UML class diagrams. Technology, Instruction, Cognition and Learning, 4(2), 4 - 28.

Barab, S., Thomas, M., Dodge, T., Carteaux, R., \& Tuzun, H. (2005). Making learning fun: Quest Atlantis, a game without guns. Educational Technology Research and Development, 53(1), 86-107.

Barak, M., \& Dori, Y. J. (2005). Enhancing undergraduate students' chemistry understanding through project-based learning in an IT environment. Science Education, 89(1), 117-139.

Barak, M., Harward, J., Kocur, G., \& Lerman, S. (2007). Transforming an introductory programming course: From lectures to active learning via wireless laptops. Journal of Science Education and Technology, 16(4), 325-336.

Bell, P., Hoadley, C. M., \& Linn, M. C. (2004). Design-based research in education. In M. C. Linn, E. A. Davis \& P. Bell (Eds.), Internet environments for science education (pp. 73-85). Mahwah, NJ: L. Erlbaum Associates.

Biggs, J., \& Tang, C. (2007). Teaching for quality learning at university (3rd ed.). Maidenhead Berkshire England: Open university Press.

Borgida, A., Brachman, R. J., Coombs, M. J., \& Sowa, J. F. (1991). Principles of semantic networks : explorations in the representation of knowledge. San Mateo, CA: Kaufman.

Borning, A., Freeman-Benson, B., \& Wilson, M. (1992). Constraint hierarchies. LISP and symbolic computation, 5(3), 223-270. doi: 10.1007/bf01807506

Bouras, C., \& Tsiatsos, T. (2006). Educational virtual environments: Design rationale and architecture. Multimedia Tools and Applications, 29(2), 153-173.

Boyer, E. L. (1990). Scholarship reconsidered: Priorities of the professoriate. In CF (Ed.). Princeton, N.J.: Carnegie Foundation for the Advancement of Teaching.

Breakey, K. M., Levin, D., Miller, I., \& Hentges, K. E. (2008). The use of scenario-based-learning interactive software to create custom virtual laboratory scenarios for teaching genetics. Genetics, 179(3), 1151.

Brusilovsky, P. (2004). KnowledgeTree: A distributed architecture for adaptive e-learning. Proceedings of the 13th international World Wide Web conference on Alternate track papers \& posters, 104-113. 
Burkhardt, H. (2006). From design research to large scale impact. In J. v. d. Akker, K. Gravemeijer, S. McKenney \& N. Nieveen (Eds.), Educational design research (pp. 121-150). London/New York: Routledge.

Busstra, M. C., Geelen, A., Feskens, E. J., Hartog, R. J. M., \& van 't Veer, P. (2008). Design and development of digital learning material for applied data analysis. The American Statistician, 62(4), $329-338$.

Busstra, M. C., Hartog, R., Kersten, S., \& Müller, M. (2007). Design guidelines for the development of digital nutrigenomics learning material for heterogeneous target groups. Advances in Physiology Education, 31(March), 67 - 75.

Busstra, M. C., Hartog, R., \& van 't Veer, P. (2005). The role of active manipulation of three-dimensional scatter plots in understanding the concept of confounding. Epidemiologic Perspectives \& Innovations, $2(6)$.

Cafolla, R. (2006). Project MERLOT: Bringing peer review to web-based educational resources. Journal of Technology and Teacher Education, 14(2), 313-323.

Chen, P. P.-S. (1976). The entity-relationship model-toward a unified view of data. ACM TODS, 1(1).

Clements, P., Kazman, R., \& Klein, M. (2002). Evaluating software architectures. Indianapolis IN: Pearson Education.

Cobb, P., Confrey, J., diSessa, A., Lehrer, R., \& Schauble, L. (2003). Design experiments in educational research. Educational Researcher, 32(1), 9-13. doi: 10.3102/0013189x032001009

Coffey, J., \& Koonce, R. (2008). MODeLeR: A virtual constructivist learning environment and methodology for object-oriented design. Journal of Computers in Mathematics and Science Teaching, $27(2), 129-147$.

Collis, B., \& Moonen, J. (2001). Flexible learning in a digital world: Experiences and expectations. London: Kogan Page Limited.

Collis, B., \& Strijker, A. (2002). New pedagogies and re-usable learning objects: Toward a different role for an LMS. In P. Barker \& S. Rebelsky (Eds.), Proceedings of World Conference on Educational Multimedia, Hypermedia and Telecommunications 2002 (pp. 334-339). Chesapeake, VA: AACE.

Costelloe, E., Sherry, E., \& Magee, P. (2009). Experiences gained using a set of SCORM compliant reusable learning objects for teaching programming. International Journal on E-learning, 8(2), 175191.

Cristea, A., \& Garzotto, F. (2004). Designing patterns for adaptive or adaptable educational hypermedia: A taxonomy. In L. Cantoni \& C. McLoughlin (Eds.), Proceedings of World Conference on Educational Multimedia, Hypermedia and Telecommunications (pp. 808-813). Lugano: AACE Chesapeake VA.

Dede, C. (2004). If design-based research is the answer, what is the question? A commentary on Collins, Joseph, and Bielaczyc; diSessa and Cobb; and Fishman, Marx, Blumenthal, Krajcik, and Soloway Journal of the Learning Sciences, , 13(1), 105 - 114.

Deek, F. P., \& McHugh, J. A. (2003). A case study in an integrated development and problem solving environment. Journal of Interactive Learning Research, 14(3), 333-359.

Dennis, A., Wixom, B. H., \& Tegarden, D. (2005). Systems analysis and design with UML Version 2.0 (2nd ed.): John Wiley and Sons.

Derntl, M. (2004). The person-centered e-learning pattern repository: Design for reuse and extensibility Proceedings of Edmedia 2004 (pp. 3856 -3861). Lugano: AACE.

Design-Based Research Collective. (2003). Design-based research: An emerging paradigm for educational inquiry. Educational Researcher, 32(1), 5-8. doi: 10.3102/0013189x032001005 
Diederen, J., Gruppen, H., Hartog, R., Moerland, G., \& Voragen, A. G. J. (2003). Design of activating digital learning material for food chemistry education. Chemistry Education: Research and Practice, 4(3), 353-371.

Diederen, J., Gruppen, H., Hartog, R., \& Voragen, A. G. J. (2006). Design and evaluation of digital assignments on research experiments within food chemistry. Journal of Science Education and Technology, 15(3,4), 227 - 246.

Dimitrova, M., \& Suthcliffe, A. (1999). Designing instructional multimedia applications: Key practices and design patterns. Paper presented at the EDMEDIA '99, Seatle.

Ding, L., Chabay, R., Sherwood, B., \& Beichner, R. (2006). Evaluating an electricity and magnetism assessment tool: Brief electricity and magnetism assessment. Physical review special topics- Physics Education Research, 2(1), 1-7.

Draaijer, S., \& Hartog, R. J. M. (2007). Design patterns for digital item types in higher education. $e$ Journal of Instructional Science and Technology (e-JIST), 10(October).

Duval, E. (2005). A learning object manifesto - Towards share and reuse on a global scale. Paper presented at the Presentation at E-learning Conference, , Brussels, Belgium,.

Duval, E., Hodgins, W., Rehak, D., \& Robson, R. (2004). Learning objects symposium Special Issue Editorial, Journal of Educational Multimedia and Hypermedia 13(4), 1-195.

Ebner, M., \& Holzinger, A. (2007). Successful implementation of user-centered game based learning in higher education: An example from civil engineering. Computers \& Education, 49(3), 873-890.

Eckert, C., \& Clarkson, J. (2005). The reality of design. In J. Clarkson \& C. Eckert (Eds.), Design process improvement - A review of current practice (pp. 1 - 29). London: Springer.

Eekels, J., \& Roozenburg, N. F. M. (1991). A methodological comparison of the structures of scientific research and engineering design: Their similarities and differences. Design Studies, 12(4), 197-203.

ESCOT. (2001). Educational software components for tomorrow. Retrieved 10 august 2012, from http://www.merlot.org/merlot/viewMaterial.htm?id=284173

Fallman, D. (2007). Why research-oriented design isn't design-oriented research: On the tensions between design and research in an implicit design discipline. Knowledge, Technology \& Policy, 20(3), 193-200.

Ferdig, R. E., Mishra, P., \& Zhao, Y. (2004). Component architectures and web-based learning environments. Journal of Interactive Learning Research, 15(1), 75-90.

Gamma, E., Helm, R., Johnson, R., \& Vlissides, J. (1994). Design patterns: Elements of reusable objectoriented software. Amsterdam: Addison and Wesley Professional Computing Series.

Garvin-Doxas, K., \& Klymkowsky, M. W. (2008). Understanding randomness and its impact on student learning: Lessons learned from building the biology concept inventory (BCI). CBE Life Sci Educ, 7(2), 227-233. doi: 10.1187/cbe.07-08-0063

Gerosa, M. A., Fuks, H., \& Lucena, C. (2003). Analysis and design of awareness elements in collaborative digital environments: A case study in the AulaNet learning environment. Journal of Interactive Learning Research, 14(3), 315-332.

Gibbons, M. (1999). Science's new social contract with society. Nature, 402 (6761)(December), C81-C84.

Gibbons, M. (2002). Innovation and the developing system of knowledge production, from http://edie.cprost.sfu.ca/summer/papers/michael.gibbons.html

Gibbons, M., Limoges, C., Nowotny, H., Schwartzman, S., Scott, P., \& Trow, M. (1994). The new production of knowledge. Thousand Oaks: Sage.

Gijbels, D., Dochy, F., Van den Bossche, P., \& Segers, M. (2005). Effects of problem-based learning: A meta-analysis from the angle of assessment. Review of Educational Research, 75(1), 27-61. doi: $10.3102 / 00346543075001027$ 
Gilb, T. (1997). Towards the engineering of requirements. Requirements Engineering, 2(3), 165-169.

Glinz, M. (2005). Rethinking the notion of non-functional requirements. Proceedings of the Third World Congress for Software Quality (Vol. II, pp. 55 - 64). Munich.

Goodyear, P. (2005). Educational design and networked learning: Patterns, pattern languages and design practice. Australasian Journal of Educational Technology, 21(1), 82-101.

Gravemeijer, K., \& Cobb, P. (2006). Design research from a learning design perspective. In J. v. d. Akker, K. Gravemeijer, S. McKenney \& N. Nieveen (Eds.), Educational design research (pp. 17 - 51). Abingdon: Routledge.

Gronlund, N. E. (1965). Measurement \& evaluation in teaching (3rd ed.). New York: Macmillan Publishing Company.

Gross, M. D. (1985). Design as exploring constraints. PhD PhD Thesis, Massachusetts Institute of Technology.

Gross, M. D., Ervin, S. M., Anderson, J. A., \& Fleisher, A. (1988). Constraints: Knowledge representation in design. Design Studies, 9(3), 133-143.

Gütl, C., \& Pivec, M. (2003). A multimedia knowledge module virtual tutor fosters interactive learning. Journal of Interactive Learning Research, 14(2), 231-258.

Gütl, C., Pivec, M., Trummer, C., García-Barrios, V. M., Mödritscher, F., Pripfl, J., \& Umgeher, M. (2005). AdeLE (Adaptive e-Learning with Eye-Tracking): Theoretical Background, System Architecture and Application Scenarios. EURODL, 2005-2012.

Harrigan, K., Carey, T., \& Ld Team, W. (2005). Community Building in a Co-operative Learning Object Repository. Paper presented at the World Conference on Educational Multimedia, Hypermedia and Telecommunications 2005, Montreal, Canada.

Hartog, R., Beulens, A., \& Tramper, J. (2010). Faculty-based design-oriented research on digital learning materials: Defining project goals. In Z. W. Abas, I. Jung \& J. Luca (Eds.), Proceedings of Global Learn Asia Pacific 2010 (pp. 1418-1427). Penang, Malaysia: AACE.

Hestenes, D., Wells, M., \& Swackhamer, G. (1992). Force concept inventory. The Physics Teacher, 30, 141 $-158$.

Hevner, A. R., March, S. T., Park, J., \& Ram, S. (2004). Design science in information systems research. MIS Quarterly, 28(1), 75 - 105.

Hiddink, G. W. (2001). ADILE: Architecture of a database-supported learning environment. Journal of Interactive Learning Research, 12(2), 301-319.

Holmström, J. B., Ketokivi, M., \& Hameri, A.-P. (2009). Bridging practice and theory: A design science approach. Decision Sciences, 40(1), 65 - 87.

Holzinger, A., Emberger, W., Wassertheurer, S., \& Neal, L. (2008). Design, development and evaluation of online interactive simulation software for learning human genetics. Elektrotechnik und Informationstechnik, 125(5), 190-196.

Holzinger, A., Kickmeier-Rust, M. D., Wassertheurer, S., \& Hessinger, M. (2009). Learning performance with interactive simulations in medical education: Lessons learned from results of learning complex physiological models with the HAEMOdynamics SIMulator. Computers \& Education, 52(2), 292-301.

IEEE. (2008). IEEE home page Retrieved 2008, 2008, from http://www.iee.org/

IMS. (2006). IMS learning resource meta-data specification Version 1.3 - Final specification. Retrieved August 29 2012, from http://www.imsglobal.org/metadata/

IMS Global Learning Consortium. (2007). About the IMS Global Learning Consortium. Retrieved 10 August 2012, from http://www.imsglobal.org/aboutims.html 
Jara, C. A., Candelas, F. A., Torres, F., Dormido, S., Esquembre, F., \& Reinoso, O. (2009). Real-time collaboration of virtual laboratories through the Internet. Computers \& Education, 52(1), 126-140.

Jensen, M. B. (2009). Using web-based resources to incorporate labVIEW into an instrumental analysis course. Journal of Chemical Education, 86(4), 525. doi: 10.1021/ed086p525

Jeschke, S., Richter, T., Scheel, H., \& Thomsen, C. (2007). On remote and virtual experiments in elearning in statistical mechanics and thermodynamics. Journal of Software, 6(2), 76 - 85.

Jonassen, D. (2008). Instructional design as design problem solving: An iterative process. Educational Technology, XLVII(3), 21-26.

Kassahun, A., Beulens, A., \& Hartog, R. (2006). Providing author-defined state data storage to learning objects. Journal of Educational Technology and Society, 9(2), 19 -32.

Kelly, A. (2004). Design research in education: Yes, but is it methodological? Journal of The Learning Sciences, 13(1), 115-128.

Kelly, A. E. (2006). Quality criteria for design research. In J. v. d. Akker, K. Gravemeijer, S. McKenney \& N. Nieveen (Eds.), Educational design research (pp. 107 - 117). Abingdon: Routledge.

Klymkowsky, M. W., \& Garvin-Doxas, K. (2008). Recognizing student misconceptions through ed's tools and the biology concept inventory. PLoS Biol, 6(1), e3.

Klymkowsky, M. W., Garvin-Doxas, K., \& Zeilik, M. (2003). Bioliteracy and teaching efficacy: What biologists can learn from physicists. Cell Biol Educ, 2(3), 155-161. doi: 10.1187/cbe.03-03-0014

Koohang, A., Floyd, K., \& Stewart, C. (2011). The LO Creator: Design of an open source learning objects authoring tool. Interdisciplinary Journal of E-Learning and Learning Objects Volume, 7, 111 - 123. Retrieved from http://www.ijello.org/Volume7/IJELLOv7p111-123Koohang746.pdf

Koper, R., \& Bennett, S. (2008). Learning design: Concepts. In P. Bernus, J. Błażewicz, G. Schmidt \& M. Shaw (Eds.), Handbook on information technologies for education and training (pp. 135-154): Springer Berlin Heidelberg.

Krauss, F., \& Ally, M. (2005). A study of the design and evaluation of a learning object and implications for content development. Interdisciplinary Journal of Knowledge and Learning Objects (IJELLO), 1, 1-22. Retrieved from http://www.ijello.org/Volume1/v1p001-022Krauss.pdf

Kroes, P. (2002). Design methodology and the nature of technical artefacts. Design Studies, 23(3), 287-302.

Kuchcinski, K. (2001). Constraints-driven design space exploration for distributed embedded systems. Journal of Systems Architecture, 47(3-4), 241-261.

Kuechler, B., \& Vaishnavi, V. (2011). Promoting relevance in IS Research: An informing system for design science research. Informing Science: the International Journal of an Emerging Transdiscipline, 14, 125-138. Retrieved from http://www.inform.nu/Articles/Vol14/ISJv14p125-138Kuechler570.pdf

Kuhn, T. S. (1973). The structure of scientific revolutions (2nd ed.). Chicago: The University of Chicago.

Laffey, J., Amelung, C., \& Goggins, S. (2009). A context awareness system for online learning: Design based research. International Journal on E-learning, 8(3), 313-330.

Lamsweerde, A. v. (2001). Goal-oriented requirements engineering: A guided tour Proceedings of the 5th International Symposium on Requirements Engineering (Re '01) (pp. 249 - 261). Toronto: IEEE.

Larkin, J. H., Scheftic, C., \& Chabay, R. W. (1990). An applied science of instructional design. In M. Gardner, J. G. Greeno, F. Reif, A. H. Schoenfield, A. diSessa \& E. Stage (Eds.), Towards a scientific practice of science education (pp. 163 - 179). Hillsdale, NJ: L. Erlbaum Associates.

Laurillard, D. (2002). Rethinking university teaching A Conversational framework for the effective use of learning technologies (2nd ed.). London: Routledge Falmer

Laurillard, D. (2008). The teacher as action researcher: Using technology to capture pedagogic form. Studies in Higher Education, 33(2), 139 - 154. 
Lawson, B. (2006). How designers think: The design process demystified (4th ed.). London: Elsevier.

Lijnse, P. L. (2003). Developmental research: Its aims, methods and outcomes. In D. Kernl (Ed.), Proceedings of the 6th ESERA PhD Summerschool.

Limniou, M., \& Whitehead, C. (2010). Online general pre-laboratory training course for facilitating first year chemical laboratory use. Cypriot Journal of Educational Sciences, 5(1).

Lundvall, B.-Ä., Hargreaves, D., \& Saussois, J.-M. (2000). Knowledge management in the learning society: Centre for Educational Research and Innovation.

March, S. T., \& Smith, G. F. (1995). Design and natural science research on information technology. Decision Support Systems, 15(4), 251 - 266.

McKenney, S., \& van den Akker, J. (2005). Computer-based support for curriculum designers: A case of developmental research. Educational Technology Research and Development, 53(2), 41-66.

Merriënboer, J. J. G. v. (1997). Training complex cognitive skills: A four-component instructional design model for technical training. Englewood Cliffs, NJ: Educational Technology Publications.

Merriënboer, J. J. G. v., \& Kirschner, P. A. (2007). Ten steps to complex learning. Mahwah New Jersey: Lawrence Erlbaum Associates.

Miller, H., \& Upton, D. (2008). Computer manipulatives in an ordinary differential equations course: Development, implementation, and assessment. Journal of Science Education and Technology, 17(2), 124-137.

Mingers, J. (2001). Combining IS research methods. Information Systems Research, 12(3), 240-259.

Mislevy, R. J., Hamel, L., Fried, R., Gaffney, T., Haertel, G., Hafter, A., . . Wenk, A. (2003). Design patterns for assessing science inquiry. In A. M. Colker, G. D. Haertel, R. Mislevy, K. Krause \& L. P. Theis (Eds.), PADI principled assessment designs for inquiry (pp. 97). Menlo Park: Center for Technology in Learning (SRI International).

Moonen, J. (1999). The design and prototyping of digital learning material: Some new perspectives. In J. v. d. Akker, R. M. Branch, K. Gustafson, N. Nieveen \& T. Plomp (Eds.), Design approaches and tools in education and training (pp. 95-111). Dordrecht/Boston/London: Kluwer.

Moust, J. H. C., \& Schmidt, H. G. (1998). Probleemgestuurd Onderwijs. Groningen: Wolters-Noordhof.

Navarro, E. O., \& Hoek, A. V. d. (2005). Design and evaluation of an educational software process simulation environment and associated model Proceedings of the Eighteenth Conference on Software Engineering Education and Training (pp. 25-32). Ottawa, Canada: IEEE.

Nijholt, A. (2006). Towards the automatic generation of virtual presenter agents. Informing Science, 9, $97-$ 110. Retrieved from http://www.inform.nu/Articles/Vo19/v9p097-110Nijholt78.pdf

Nonaka, I., \& Takeuchi, H. (1995). The knowledge-creating company. New York: Oxford University Press.

Ohlsson, S., \& Mitrovic, A. (2006). Constraint-based knowledge representation for individualized instruction. Computer Science and Information Systems, 3(1), 1-22.

Ong, S. K., \& Mannan, M. A. (2004). Virtual reality simulations and animations in a web-based interactive manufacturing engineering module. Computers \& Education, 43(4), 361-382.

Österle, H., Becker, J., Frank, U., Hess, T., Karagiannis, D., Krcmar, H., . . . Sinz, E. J. (2011). Memorandum on design-oriented information systems research. European Journal of Information Systems, 20(1), 7-10.

Patton, M. Q. (2002). Qualitative research and evaluation methods (3rd ed.). Thousand Oaks London: Sage Pub.

Paulsson, F., \& Naeve, A. (2006). Virtual workspace environment (VWE): A taxonomy and service oriented architecture framework for modularized virtual learning environments - Applying the learning object concept to the VLE. International Journal on E-learning, 5(1), 45-57. 
Peffers, K., Tuunanen, T., Rothenberger, M. A., \& Chatterjee, S. (2007). A design science research methodology for information systems research. Journal of Management Information Systems, 24(3), 45-77.

Polanyi, M. (1969). Personal knowledge (3rd ed.). London: Routledge \& Kegan Paul.

Reyes-Palomares, A., Sánchez-Jiménez, F., \& Medina, M. A. (2009). First steps in computational systems biology: A practical session in metabolic modeling and simulation. Biochemistry and Molecular Biology Education, 37(3), 178-181.

Richey, R. C., \& Klein, J. D. (2007). Design and development research: Methods, strategies, and issues. Mahwah: Lawrence Erlbaum Assoc Inc.

Richey, R. C., Klein, J. D., \& Nelson, W. A. (2004). Developmental research: Studies of instructional design and development. In D. H. Jonassen (Ed.), Handbook of research on educational communications and technology (2nd ed., pp. 1099 - 1130). Mahwah NJ: L. Erlbaum Associates.

Ritzhaupt, A. D. (2010). Learning object systems and strategy: A description and discussion. Interdisciplinary Journal of E-Learning and Learning Objects Volume, 6, 217 - 238. Retrieved from http://www.ijello.org/Volume6/IJELLOv6p217-238Ritzhaupt701.pdf

Rodríguez-Caso, C., Sánchez-Jiménez, F., \& Medina, M. A. (2002). A modeling and simulation approach to the study of metabolic control analysis. Biochemistry and Molecular Biology Education, 30(3), 169171.

Romiszowski, A. J. (1984). Designing instructional systems. New York: Nichols Publishing Company.

Roschelle, J., Digiano, C., Koutlis, M., Repenning, A., Jackiw, A., \& Suthers, D. (1999). Developing educational software components. IEEE Computer, 32(9), 50-58.

Rosé, C. P., Roque, A., \& Bhembe, D. (2002). An efficient incremental architecture for robust interpretation.

Russell, J. D. (1974). Modular instruction: A guide to the design, selection, utilization, and evaluation of modular materials. Minneapolis: Burgess Publishing Co.

Saade, R., Nebebe, F., \& Mak, T. (2011). Knowledge management systems development: Theory and practice. Interdisciplinary Journal of Information, Knowledge, and Management, 6, 35-72. Retrieved from http://www.ijikm.org/Volume6/IJIKMv6p035-072Saade472.pdf

Sampson, D., Karagiannidis, C., \& Cardinali, F. (2002). An architecture for web-based e-learning promoting re-usable adaptive educational e-content. Educational Technology \& Society, 5(4), 27-36.

Sampson, D. G., \& Karampiperis, P. (2006). Towards next generation activity-based learning systems. International Journal on E-Learning, 5(1), 129-149.

Sandvoss, L. M., Harwood, W. S., Korkmaz, A., Bollinger, J. C., Huffman, J. C., \& Huffman, J. N. (2003). Common molecules: Bringing research and teaching together through an online collection. Journal of Science Education and Technology, 12(3), 277-284.

Schaaf, H. v. d., Tramper, J., Hartog, R., \& Vermuë, M. (2006). A digital tool set for systematic model design in process-engineering education. European Journal of Engineering Education, 31(5), 619 629.

Schaaf, H. v. d., Vermue, M., Tramper, J., \& Hartog, R. (2003). A design environment for downstream processes for bioprocess-engineering students. European Journal of Engineering Education, 28(4), 507-521.

Schaaf, H. v. d., Vermuë, M., Tramper, J., \& Hartog, R. (2006). Support of modelling in processengineering education. Computer Applications in Engineering Education, 14(3), 161 - 168.

Schmidt, A., \& Winterhalter, C. (2004). User context aware delivery of e-learning material: Approach and architecture. Journal of Universal Computer Science (JUCS), 10, 28-36.

Schmidt, H. G. (1983). Problem-based learning: Rationale and description. Medical Education, 17, 11-16. 
Schönborn, K. J., \& Anderson, T. R. (2008). Bridging the educational research-teaching practice gap. Biochemistry and Molecular Biology Education, 36(5), 372-379.

Sessink, O. D. T., Beeftink, H. H., \& Hartog, R. J. M. (2005). Database functionality for learning objects. Technology, Instruction, Cognition and Learning, 2(4).

Sessink, O. D. T., Beeftink, H. H., Tramper, J., \& Hartog, R. J. M. (2007). Proteus: A lecturer-friendly adaptive tutoring system. Journal of Interactive Learning Research, 18(4), 533-554.

Sessink, O. D. T., Beeftink, R., Tramper, J., \& Hartog, R. (2003, 9-11 july). Author-defined storage in the next generation learning management systems. Paper presented at the 3rd IEEE International Conference on Advanced Learning Technologies (ICALT 2003), Athens Greece.

Sessink, O. D. T., Beeftink, R., Tramper, J., \& Hartog, R. (2006). Virtual parameter-estimation experiments in bioprocess-engineering education. Bioprocess and Biosystems Engineering, 28, 379 - 386.

Sessink, O. D. T., van der Schaaf, H., Beeftink, H. H., Hartog, R. J. M., \& Tramper, J. (2007). Web-based education in bioprocess engineering. Trends in Biotechnology, 25(1), 16 - 23.

Shanklin, C. W., Huang, H., Lee, K.-E., Ok, C., Seo, S., \& Flores, S. A. (2003). Developing web-based interdisciplinary modules to teach solid waste/residue management in the food chain. Journal of Food Science Education, 2(3), 47-52.

Sheremetov, L., \& Arenas, A. G. (2002). EVA: An interactive web-based collaborative learning environment. Computers \& Education, 39(2), 161-182.

Shin, D., Yoon, E. S., Lee, K. Y., \& Lee, E. S. (2002). A web-based, interactive virtual laboratory system for unit operations and process systems engineering education: Issues, design and implementation. Computers \& Chemical Engineering, 26(2), 319-330.

Shulman, L. (1987). Knowledge and teaching: Foundations of the new reform. Harvard Educational Review, 57, 1 - 22.

Shulman, L. (2001). Inventing the future. In P. Hutchins (Ed.), Approaches to the scholarship of teaching and learning. Menlo Park CA: Carnegie Foundation.

Siddiqui, A., Khan, M., \& Akhtar, S. (2008). Supply chain simulator: A scenario-based educational tool to enhance student learning. Computers \& Education, 51(1), 252-261.

Sierra, J. L., Moreno-Ger, P., Martínez-Ortiz, I., López-Moratalla, J., \& Fernández-Manjón, B. (2005). Building learning management systems using IMS standards: Architecture of a manifest driven approach. In R.W.H.Lau (Ed.), Advances in Web-Based learning ICWL 2005 (pp. 144 - 156). BerlinHeidelberg: Springer Verlag.

Simon, H. A. (1996). The sciences of the artificial (3rd ed.). Cambridge, Mass.: MIT Press.

Sjostrom, J., \& Agerfalk, P. J. (2009). An analytic framework for design-oriented research concepts Proceedings of the Fifteenth Americas Conference on Information Systems (pp. 302 308). San Francisco: AMCIS 2009.

Smith-Gratto, K., Wicks, D., \& Berger, C. (2002). MERLOT: Reaping the on-line vineyard. Paper presented at the World Conference on Educational Multimedia, Hypermedia and Telecommunications 2002, Denver, Colorado, USA.

Sommerville, I. (2007). Software engineering (8th ed.): Pearson Education.

Stone, D. C. (2007). Teaching chromatography using virtual laboratory exercises. Journal of Chemical Education, 84(9), 1488 - 1496.

Toumoto, T., Horiguchi, T., Hirashima, T., \& Takeuchi, A. (2006). Interactive environment to support learning by designing physics experiments. Paper presented at the World Conference on E-Learning in Corporate, Government, Healthcare, and Higher Education 2006, Honolulu, Hawaii, USA.

Trigwell, K., Martin, E., Benjamin, J., \& Prosser, M. (2000). Scholarship of teaching: A model. Higher Education Research \& Development, 19(2), 155-168. 
Underwood, J. S., Hoadley, C., Lee, H. S., Hollebrands, K., DiGiano, C., \& Renninger, K. A. (2005). IDEA: Identifying design principles in educational applets. Educational Technology Research and Development, 53(2), 99 - 112.

van Aken, J. E. (2005). Management research as a design science: Articulating the research products of mode 2 knowledge production in management1. British Journal of Management, 16, 19 - 36

van den Akker, J., Gravemeijer, K., McKenney, S., \& Nieveen, N. (2006a). Introducing educational design research. In J. v. d. Akker, K. Gravemeijer, S. McKenney \& N. Nieveen (Eds.), Educational design research (pp. 3 -7). Abingdon: Routledge.

van den Akker, J., Gravemeijer, K., McKenney, S., \& Nieveen, N. (Eds.). (2006b). Educational design research. London/New York: Routledge \& Kegan Paul.

Verschuren, P., \& Hartog, R. (2005). Evaluation in design oriented research. Quality and Quantity, 39(6), 733-762.

Visscher-Voerman, I. (1999a). Design approaches in training and education. Enschede: Printpartners Ipskamp.

Visscher-Voerman, I. (1999b). Educational design and development: A study of Dutch design practices. In J. v. d. Akker, R. M. Branch, K. Gustafson, N. Nieveen \& T. Plomp (Eds.), Design approaches and tools in education and training. Dordrecht/Boston/London: Kluwer.

Wallace, J., Philpott, A., O'Sullivan, M., \& Ferris, M. (2006). Optimal rig design using mathematical programming. 2nd High Performance Yacht Design Conference, Auckland (pp. 14-16).

Wilmsen, T., Bisseling, T., \& Hartog, R. (2002). Web based learning support for experimental design in molecular biology. In P. Barker \& S. Rebelsky (Eds.), Proceedings of ED-Media 2002 (pp. 20632068). Denver.

Wilson, C. D., Anderson, C. W., Heidemann, M., Merrill, J. E., Merritt, B. W., Richmond, G., . . Parker, J. M. (2006). Assessing students' ability to trace matter in dynamic systems in cell biology. CBE Life Sci Educ, 5(4), 323-331. doi: 10.1187/cbe.06-02-0142

Wilson, S. (2005). 3 Architectures to support authoring and content management with learning design. In R. Koper \& C. Tattersall (Eds.), Learning design (pp. 408). Berlin-Heidelberg: Springer.

WMMRC. (2007). Wageningen MultiMedia Research Centre Retrieved 24 January 2013, from http://wmmrc.nl/

Yen, C., \& Li, W.-J. (2003). Web-based learning and instruction support system for pneumatics. Computers \& Education, 41(2), 107-120.

Yin, R. K. (2003). Case study research: Design and methods (3rd ed.). Thousand Oaks, CA: Sage.

Yokaichiya, D. K., Galembeck, E., \& Torres, B. B. (2004). Adapting a biochemistry course to distance education. Biochemistry and Molecular Biology Education, 32(1), 27-29.

Ziman, J. (2002). Real science: what it is and what it means. Cambridge: Cambridge University Press.

Zimmerer, C., Thiele, S., Salzer, R., Krauseneck, A., \& Körndle, H. (2003). Internet teaching: Laboratory course in analytical chemistry. Microchimica Acta, 142(3), 153-159. 


\section{Biographies}
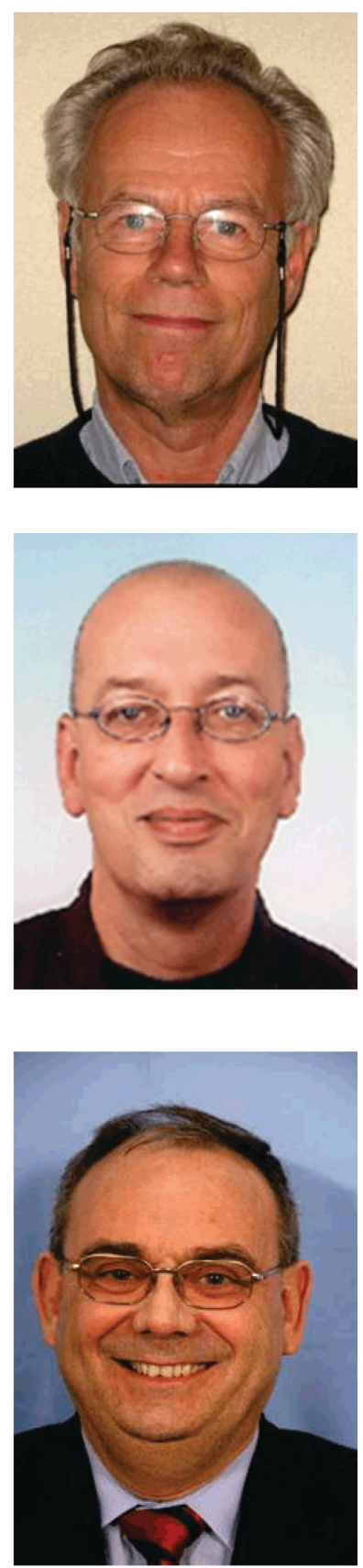

Rob J.M. Hartog leads Wageningen MultiMedia Research Centre (WMMRC - see http://wmmrc.nl/). WMMRC is a small business unit within the Social Science Group of Wageningen University in the Netherlands. WMMRC supports university teachers in design and development of digital learning materials. Rob Hartog holds an M.Sc. (experimental physics) from the University of Amsterdam and a Ph.D. (e-learning) from Wageningen University.He teaches courses on information systems and management for life sciences.His research interests and publications focus on design, development, implementation, use and evaluation of digital learning resources in higher education and on design-oriented research approaches.

Huub Scholten holds an MSc in Biology (University of Amsterdam) and $\mathrm{ahD}$ in Life Sciences (Wageningen University). He is employed as senior scientist and assistant professor in Applied Systems Science by Wageningen University. He has (co-)authored almost 100 publications in domain specific model development, model application and in more generic methods and tools in his fields of interest, including knowledge management, ontologies, mathematical modelling, process support, semantic interoperability. He is project leader for WU in the research projects SmartAgriFood (FP7), cSpace (FP7) and SCALE (INTERREG). He was coordinator in HarmoniQuA (FP5) and project leader for Wageningen University in AquaStress (FP6).

Adrie J.M. Beulens is Professor of Information Systems and head of the Information Technology Group at Wageningen University in the Netherlands (since 1990). He was founding director of Wageningen Business School, member of the board of Agri Chain Competence and several other organisations with a focus on knowledge management and information systems. He is (co-) author and editor of many articles in areas such as Information Systems and E-Learning. He is active as a senior management consultant for a large variety of companies in a variety of areas encompassing information systems. He is member of a number of (inter)national professional organisations like VVS, VRI, IFIP, IAMA and GOR. 